\title{
Effects of Metazachlor on Vitellogenin Induction in Zebrafish (Danio rerio)
}

\author{
J. JURČÍKOVÁ 1 , P. MIKULA², R. DOBŠÍKOVÁ², D. NÉMETHOVÁ ${ }^{3,4}$, Z. SVOBODOVÁ ${ }^{2}$ \\ ${ }^{1}$ Institute of Public Health in Ostrava, Ostrava, Czech Republic \\ ${ }^{2}$ Department of Veterinary Public Health and Toxicology, Faculty of Veterinary Hygiene and Ecology, \\ University of Veterinary and Pharmaceutical Sciences, Brno, Czech Republic \\ ${ }^{3}$ Research Centre for Environmental Chemistry and Ecotoxicology, Masaryk University, Brno, Czech Republic \\ ${ }^{4}$ Institute of Biostatistics and Analyses, Masaryk University, Brno, Czech Republic
}

Received July 9, 2007

Accepted October 11, 2007

\begin{abstract}
Jurčíková J., P. Mikula, R. Dobšíková, D. Némethová, Z. Svobodová: Effects of Metazachlor on Vitellogenin Induction in Zebrafish (Danio rerio). Acta Vet. Brno 2007, 76: S61-S66.

The influence of metazachlor on vitellogenesis in juvenile (20 days old) zebrafish (Danio rerio) was investigated after ambient water exposure to concentrations of $0.1,1.0$ and $5.0 \mathrm{mg} \mathrm{l}^{-1}$ of the chloroacetanilide herbicide Butisan 400 SC containing approximately 35.6\% (w/w) metazachlor. After 20 days of exposure, vitellogenin concentrations in whole-body homogenates of the fish were measured by direct sandwich ELISA. The results were compared to vitellogenin concentrations in fish from both negative (no exposure) and positive (exposed to natural oestrogen 17 $\beta$-oestradiol) control groups. Exposure to Butisan $400 \mathrm{SC}$ at a concentration of $5.0 \mathrm{mg} \mathrm{l}^{-1}$ induced vitellogenin synthesis significantly compared to the control fish $(p<0.05)$. The oestrogenic effect of $17 \beta$-oestradiol was confirmed.
\end{abstract}

Butisan 400 SC; Chloroacetanilide herbicides; Endocrine disruptors; 17ß-oestradiol; Fish

Many chemicals in the environment have been shown, or are suspected, to have endocrine disrupting potential that may adversely affect the reproductive capabilities of fish (Shioda and Wakabayashi 2000). Endocrine disrupting chemicals (EDCs) are, broadly defined, natural and man-made agents present in the environment that interfere with normal endocrine function (Arcand-Hoy and Benson 1998). The best characterised group of EDCs are environmental oestrogens or xenoestrogens. These compounds can mimic the effects of natural endogenous oestrogens (Colborn et al. 1993). Effects of xenoestrogens on fish include stimulating synthesis of vitellogenin, the yolk precursor protein, in males and juveniles (Jobling et al. 1996; Harries et al. 1997; Flammarion et al. 2000); affecting the development of the gonads (Lee et al. 2003); inducing hermaphroditism, as evidenced by the presence of both testicular and ovarian tissues, (Gimeno et al. 1998; Jobling et al. 1998; Nolan et al. 2001); and reducing plasma testosterone concentrations (Folmar et al. 1996).

An important biomarker used to detect fish exposure to oestrogenic endocrine disruptors is the occurrence of phospholipoglycoprotein vitellogenin in blood plasma, liver, or wholebody homogenates of juvenile and male fish (Sumpter and Jobling 1995). Vitellogenin synthesis in fish liver is oestrogen-dependent and, hence, is normally limited to reproductive females. Vitellogenin released from the liver is transported by the blood and taken up by developing oocytes, where it is cleaved into major constituents of yolk, lipovitellin and phosvitin (Mommsen and Walsh 1988). Male and juvenile fish possess the vitellogenin gene, which remains inactive under normal conditions, but can be activated by exposure to exogenous oestrogens or xenoestrogens. Vitellogenin concentrations in male and juvenile fish can therefore provide a biomarker of exposure to environmental oestrogens (Kime 1999).

Address for correspondence:

MVDr. Přemysl Mikula

University of Veterinary and Pharmaceutical Sciences

Palackého 1-3, 61242 Brno

Czech Republic
Phone: +420541562780

Fax: +420541562 790

E-mail:pmikula@vfu.cz

http://www.vfu.cz/acta-vet/actavet.htm 
Herbicides are intended to be uniquely toxic to plants. Although plant cells differ from animal cells, it is difficult to produce herbicides that are not toxic to animals (Saunders and Harper 1994). One of the most widely and extensively used chloracetanilide herbicides is metazachlor. It is used for pre-emergence and early postemergence control of annual grasses and broad-leaved weeds in a broad spectrum of crops including maize, soybeans, peanuts, sugarcane, cotton, tobacco, oilseed rape and transplanted brassicas (Roberts 1998). Based on the results of tests of acute toxicity, metazachlor was classified as toxic to trout and moderately toxic to carp (Gangolli 1999). Since Keith (1997) included alachlor and metolachlor, the other members of the chloroacetanilide herbicide family, in the list of EDCs, the endocrine disrupting potential of metazachlor could be expected.

In the present study, the xenoestrogenic potential of metazachlor was evaluated by measuring vitellogenin concentrations in whole-body homogenates of control and experimental juvenile zebrafish (Danio rerio).

\section{Materials and Methods}

Maintenance of fish and experimental protocol

The experiment was carried out as a semistatic test, using juvenile zebrafish. After an adaptation period, juvenile zebrafish, 20 days post hatching (dph), were placed in 10 glass tanks (151) each containing 101 of water, and about 30 fish per tank. Fish were divided into 5 groups: three metazachlor treated, one $17 \beta$-oestradiol treated (positive control) and one negative control. Experimental fish were exposed to the preparation Butisan $400 \mathrm{SC}$ containing $35.6 \%(\mathrm{w} / \mathrm{w})$ metazachlor in concentrations of $0.1,1.0$, and $5.0 \mathrm{mg} \cdot \mathrm{l}^{-1}$ of tank water. For the positive control group, a stock solution of $17 \beta$-oestradiol was prepared by diluting $0.1 \mathrm{mg}$ of $17 \beta$-oestradiol (97\%, Sigma-Aldrich) in $100 \mathrm{ml}$ of $96 \%$ ethanol. One $\mathrm{ml}$ of this solution was added to the water in the tank to give a concentration of $100 \mathrm{ng} \cdot \mathrm{l}^{-1}$. The final concentration of ethanol in the tank was not greater than $0.1 \mathrm{ml} \cdot \mathrm{l}^{-1}$. The fish from the negative control group were not exposed to metazachlor or $17 \beta$-oestradiol. The baths in all tanks were changed 3 times a week. The test was replicated for each treatment, i.e. approximately 60 specimens per treatment group.

Basic physical and chemical parameters of water were measured as follows: $\mathrm{pH}$ 7.4-7.8, $\mathrm{ANC}_{45}$ (alkalinity) 3.7-3.8 mmol $\cdot l^{-1}, \mathrm{COD}_{\mathrm{Mn}} 1.6-1.9 \mathrm{mg} \cdot \mathrm{l}^{-1}, \mathrm{BOD}_{5} 1.02-1.36 \mathrm{mg} \cdot \mathrm{l}^{-1}, \mathrm{NH}_{4}^{+} 0 \mathrm{mg} \cdot \mathrm{l}^{-1}, \mathrm{NO}_{3}^{-} 24.5-31.4 \mathrm{mg} \cdot \mathrm{l}^{-1}, \mathrm{NO}_{2}^{-} 0 \mathrm{mg} \cdot \mathrm{l}^{-1}$, $\mathrm{Cl}^{-} 17.7-18.5 \mathrm{mg} \cdot \mathrm{l}^{-1}$. The water was continuously aerated, at an oxygen saturation above $60 \%$, and maintained at $25 \pm 1.5^{\circ} \mathrm{C}$.

A photoperiod of 12:12LD was maintained throughout the test. Fish were fed 3 times a day at approximately $2 \%$ of their body weight per day. During the first week fish were fed with freshly hatched brine shrimps (Artemia salina, Sanders Brine Shrimp Company Inc.). From the second week until the end of the test, fish were fed decapsulated brine shrimp eggs (Discus CZ).

Homogenisation of zebrafish and vitellogenin analysis

The concentration of vitellogenin was measured in whole-body homogenates of fish using the zebrafish vitellogenin EIA kit (Biosense Laboratories AS, Norway). At 40 dph, 12 randomly selected fish from each of the 5 groups (i.e. 6 fish from each tank) were used for vitellogenin measurement. The fish were killed in carbon dioxidesaturated water, weighed, and stored at $-80^{\circ} \mathrm{C}$ for later analysis of vitellogenin. The fish were homogenized in homogenate buffer $(50 \mathrm{mM}$ Tris- $\mathrm{HCl} \mathrm{pH} 8.0,0.02 \%$ aprotinin, $0.1 \mathrm{mM}$ phenylmethanesulfonyl fluoride) at a ratio of 1:2 (w/v). After centrifugation $\left(14585 \mathrm{~g}, 60 \mathrm{~min}, 4{ }^{\circ} \mathrm{C}\right)$, the supernatants were removed and analysed for vitellogenin by direct sandwich ELISA according to instructions provided by the manufacturer. For detailed description of parameters of the detection method you can also see Nilsen et al. (2004). The fish remaining in the tanks were used for the subsequently performed test.

Statistical analysis

The data were statistically processed using standard descriptive statistics, Kruskal-Wallis test, and a subsequent multiple comparison of the mean ranks.

\section{Results}

The vitellogenin concentrations in whole-body homogenates of juvenile zebrafish exposed to metazachlor-based herbicide Butisan $400 \mathrm{SC}$ and $17 \beta$-oestradiol were measured at $40 \mathrm{dph}$. In the whole-body homogenates of fish from the negative control group, the median vitellogenin concentration was $616 \mathrm{ng} \cdot \mathrm{ml}^{-1}$. Medians of vitellogenin concentrations in whole-body homogenates of fish exposed to Butisan $400 \mathrm{SC}$ at concentrations of 0.1 , 1.0 and $5.0 \mathrm{mg} \cdot \mathrm{l}^{-1}$ were $916 ; 556$ and $1254 \mathrm{ng} \cdot \mathrm{ml}^{-1}$, respectively. The median value of 
vitellogenin concentration in whole-body homogenates of fish exposed to $17 \beta$-oestradiol at a concentration of $100 \mathrm{ng} \cdot \mathrm{l}^{-1}$ was $10562 \mathrm{ng} \cdot \mathrm{ml}^{-1}$. (Fig. 1 and Fig. 2).

Among the groups tested, significant differences were found (Kruskal-Wallis test: $\mathrm{Q}=$ $33.68 ; \mathrm{N}=60 ; p<0.001)$. Multiple comparison of the mean ranks confirmed a significant $(p<0.05)$ increase in vitellogenin concentration in fish exposed to 17ß-oestradiol compared to fish from the control group and groups exposed to $0.1 \mathrm{mg} \cdot \mathrm{l}^{-1}$ or $1.0 \mathrm{mg} \cdot \mathrm{l}^{-1}$ of the preparation tested (see Fig. 1).

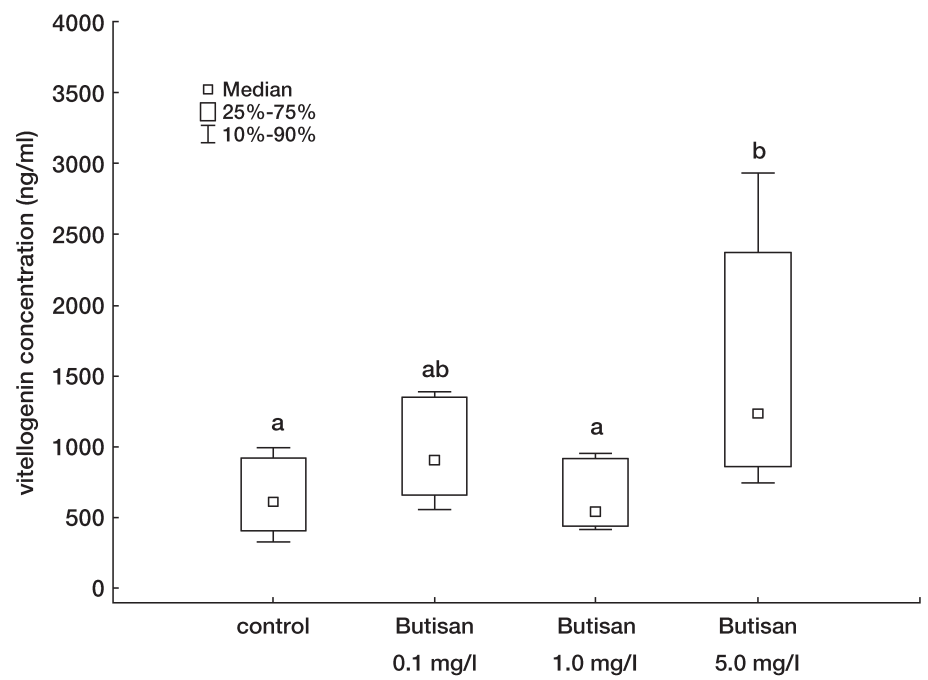

Fig. 1. Vitellogenin concentrations in whole-body homogenates of juvenile zebrafish (Danio rerio) after exposure. Groups with different alphabetical letters differ significantly at $p<0.05$.

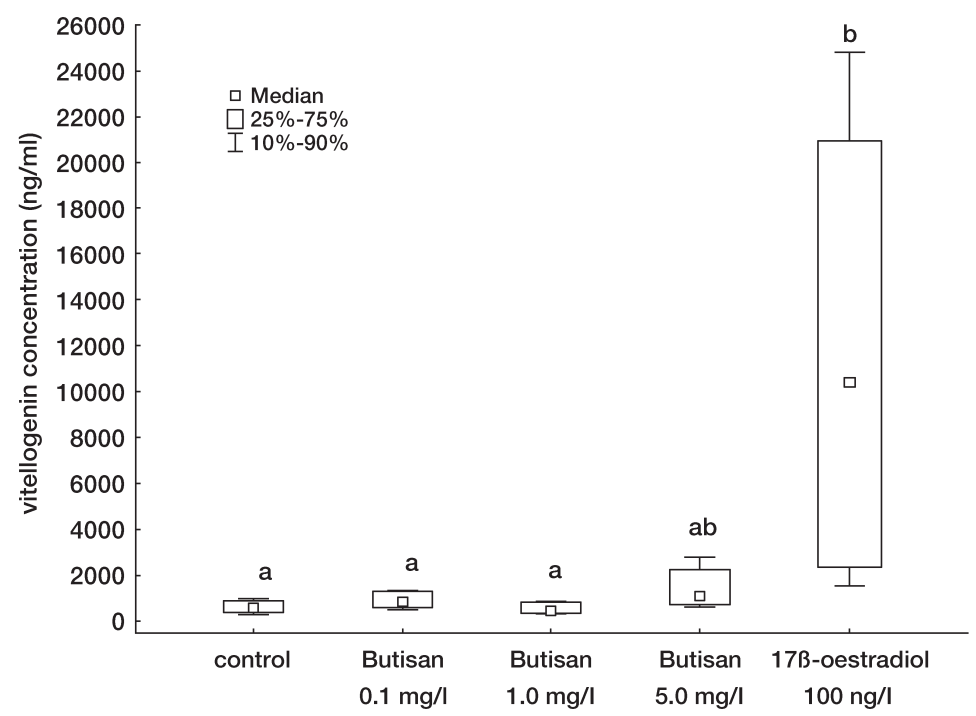

Fig. 2. Vitellogenin concentrations in whole-body homogenates of juvenile zebrafish (Danio rerio) after exposure. Groups with different alphabetical letters differ significantly at $p<0.05$. The $17 \beta$-oestradiol exposed group was excluded from the statistical analysis. 
Due to markedly higher vitellogenin concentrations in fish from the positive control group, this group was excluded from subsequent statistical analyses. Analysis of the remaining 4 groups showed significant differences (Kruskall-Wallis test: $\mathrm{Q}=12.57, \mathrm{~N}$ $=48 ; p=0.006)$. In a multiple comparison of the mean ranks, significantly $(p<0.05)$ increasing levels of vitellogenin concentration in whole-body homogenates of fish exposed to $5.0 \mathrm{mg} \cdot \mathrm{l}^{-1}$ of Butisan $400 \mathrm{SC}$ compared to fish from both the control group and the group exposed to $1.0 \mathrm{mg} \cdot \mathrm{l}^{-1}$ of Butisan $400 \mathrm{SC}$ were observed (Fig. 2).

\section{Discussion}

Environmental pollution caused by pesticides has been increasing, due to their extensive use in agriculture. Dispersal of pesticides from cultivated fields to surrounding surface waters occurs through runoff or drainage of rain or irrigation water (Larson et al. 1995). Varying levels of herbicides in the aquatic environment are common. Chloroacetanilide herbicides frequently detected in water samples include alachlor, acetochlor, metolachlor, however metazachlor was detected in the Rhine River and other large rivers in Germany at concentrations exceeding $1 \mathrm{\mu g}^{-1}$ (Haberer 1992).

Chloroacetanilide herbicides are among suspected environmental endocrine disruptors. Previous studies have established the ability of chloroacetanilide herbicides to bind to human recombinant oestrogen receptors (hERs) in vitro (Scippo et al. 2004) and to possess a weak oestrogenic effect (Klotz et al. 1996). Another in vitro study has demonstrated hER -antagonistic and hAR- (human androgen receptor) antagonistic actions of alachlor (Kojima et al. 2004). Metolachlor induced activity of a key steroidogenetic enzyme, aromatase (i.e. CYP19A1), changing endogenous testosterone to $17 \beta$-oestradiol in the human choriocarcinoma JEG-3 cell-line (Laville et al. 2006). On the other hand, the spectrum of in vivo studies dealing with the issue of endocrine disruption caused by this group of herbicides is limited. Chang et al. (2005) reported no induction of vitellogenin mRNA expression in liver of male carp (Cyprinus carpio) exposed to alachlor at concentrations of $10,25,50$, and $100 \mu \mathrm{g} \cdot \mathrm{l}^{-1}$ compared to control fish.

In the present study, Butisan $400 \mathrm{SC}$, a chloroacetanilide herbicide containing metazachlor as the active substance, was used to assess the oestrogenic potential of chloroacetanilide herbicides in zebrafish. Our results suggested that the exposure of juvenile zebrafish to metazachlor could induce oestrogenic responses. This is the first evidence of oestrogenic effects of chloroacetanilide herbicides demonstrated in fish in vivo. However, the oestrogenic response in our study was observed only in fish from the group treated with $5.0 \mathrm{mg} \cdot \mathrm{l}^{-1}$ of preparation, while in lower concentrations (i.e. 0.1 and $1.0 \mathrm{mg} \cdot \mathrm{l}^{-1}$ of Butisan $400 \mathrm{SC}$ ) the effect was not evident. Responsiveness of zebrafish to oestrogens or xenoestrogens was confirmed, since the exposure of fish to the natural oestrogen $17 \beta$-oestradiol in the concentration of $100 \mathrm{ng} \cdot 1^{-1}$ elicited vitellogenin production.

The world production and use of chloroacetanilide herbicides in agriculture are still high, and data dealing with the potential for these substances to act as EDCs are limited. Further research, with studies on other vertebrate species, is therefore necessary.

\section{Vliv metazachloru na indukci tvorby vitellogeninu u dania pruhovaného (Danio rerio)}

Vliv metazachloru na proces vitellogeneze u juvenilních danií pruhovaných (Danio rerio) ve věku 20 dnů byl zkoumán po expozici ryb chloroacetanilidovým herbicidem Butisan 400 SC obsahujícím přibližně $36.5 \%$ hmotnosti metazachloru. Dania byla exponována přípravkem přidaným do vody v koncentracích 0.1 ; 1 a $5 \mathrm{mg} / \mathrm{l}$. Po 20 dnech expozice byly pomocí přímé sendvičové ELISY změřeny koncentrace vitellogeninu $\mathrm{v}$ homogenátech těl exponovaných ryb a výsledky byly srovnány s koncentracemi vitellogeninu v rybách 
z kontrolní skupiny a ze skupiny pozitivní kontroly exponované přirozeným estrogenem $17 \beta$-estradiolem. Expozice ryb prŕpravkem Butisan $400 \mathrm{SC}$ o koncentraci $5 \mathrm{mg} / \mathrm{l}$ vedla $\mathrm{k}$ signifikantní indukci procesu vitellogeneze u exponovaných ryb $(p<0.05)$. Potvrzen byl také estrogenní účinek17 $\beta$-estradiolu.

\section{Acknowledgements}

This study was partly supported by the grants No. 6215712402 and 0021622412 of the Ministry of Education, Youth and Sports of the Czech Republic.

\section{References}

ARCAND-HOY LD, BENSON WH 1998: Fish reproduction: an ecologically relevant indicator of endocrine disruption. Environ Toxicol Chem 17: 49-57

CHANG LW, TOTH GP, GORDON DA, GRAHAM DW, MEIER JR, KNAPP CW, DENOYELLES JR FJ, CAMPBELL S, LATTIER DL 2005: Responses of molecular indicators of exposure in mesocosms: Common carp (Cyprinus carpio) exposed to the herbicides alachlor and atrazine. Environ Toxicol Chem 24: 190-197

COLBORN T, SAAL FSV, SOTO AM 1993: Developmental effects of endocrine-disrupting chemicals in wildlife and humans. Environ Health Perspect 101: 378-384

FLAMMARION P, BRION F, BABUT M, GARRIC J, MIGEON B, NOURY P, THYBAUD E, TYLER CR, PALAZZI X 2000: Induction of fish vitellogenin and alterations in testicular structure: preliminary results of estrogenic effects in chub (Leuciscus cephalus). Ecotoxicology 9: 127-135

FOLMAR LC, DENSLOW ND, RAO V, CHOW M, CRAIN DA, ENBLOM J, MARCINO J, GUILLETTE LJ JR 1996: Vitellogenin induction and reduced serum testosterone concentrations in feral male carp (Cyprinus carpio) captured near a major metropolitan sewage treatment plant. Environ Health Perspect 104: 1096-1101

GANGOLLI S 1999: The dictionary of substances and their effects. Volume 5. The Royal Society of Chemistry, Cambridge. $953 \mathrm{p}$.

GIMENO S, KOMEN H, GERRITSEN AM, BOWMER T 1998: Demasculinisation of sexually mature male common carp, Cyprinus carpio, exposed to 4-tert-pentylphenol during spermatogenesis. Aquat Toxicol 43: 93-109

HABERER K 1992: Occurrence of pesticides in surface water. In: BECKER H, HEITEFUSS R (Eds.). Determination of herbicides in aquatic ecosystems. Johannes Gutenburg-University Mainz, Mainz, pp. 5-24

HARRIES JE, SHEAHAN DE, JOBLING S, MATTHIESSEN P, NEALL P, SUMPTER J, TAYLOR T, ZAMAN N 1997: Estrogenic activity in five United Kingdom rivers detected by measurement of vitellogenesis in caged male trout. Environ Toxicol Chem 16: 534-542

JOBLING S, SHEAHAN D, OSBORNE JA, MATHIESSEN P, SUMPTER JP 1996: Inhibition of testicular growth in rainbow trout (Oncorhynchus mykiss) exposed to estrogenic alkylphenolic chemicals. Environ Toxicol Chem 15: 194-202

JOBLING S, NOLAN M, TYLER CR, BRIGHTY G, SUMPTER JP 1998: Widespread sexual disruption in wild fish. Environ Sci Technol 32: 2498-2506

KEITH LH 1997. Environmental endocrine disruptors. John Wiley and Sons, New York. 1232 pp.

KIME DE 1999: A strategy for assessing the effects of xenobiotics on fish reproduction. Sci Total Environ 225: 3-11

KLOTZ DM, BECKMAN BS, HILL SM, MCLACHLAN JA, WALTERS MR, ARNOLD SF 1996: Identification of environmental chemicals with estrogenic activity using a combination of in vitro assays. Environ Health Perspect 104: 1084-1089

KOJIMA H, KATSURA E, TAKEUCHI S, NIIYAMA K, KOBAYASHI K 2004: Screening for estrogen and androgen receptor activities in 200 pesticides by in vitro reporter gene assays using Chinese hamster ovary cells. Environ Health Perspect 112: 524-531

LARSON SJ, CAPEL PD, GOOLSBY DA, ZAUGG SD, SANDSTROM MW 1995: Relations between pesticide use and riverine flux in the Mississippi River basin. Chemosphere 31: 3305-3321

LAVILLE N, BALAGUER P, BRION F, HINFRAY N, CASELLAS C, PORCHER J-M, AIT-AISSA S 2006: Modulation of aromatase activity and mRNA by various selected pesticides in the human choriocarcinoma JEG-3 cell line. Toxicology 228: 98-108

LEE WK, LEE KW, KWAK EJ, YANG SW, YANG KS, PARK JC, JOO HS, LEE WJ, LEE WB 2003: Effects of environmental endocrine disruptors on the sex differentiation in Korean rockfish, Sebastes schlegeli. Water Sci Technol 47: 65-70

MOMMSEN TP, WALSH PJ 1988: Vitellogenesis and oocyte assembly. In: HOAR WS, RANDALL DJ (Eds.). Fish physiology. Academic Press, New York, pp. 347-406.

NILSEN BM, BERG K, EIDEM JK, KRISTIANSEN SI, BRION F, PORCHER JM, GOKSOYR A. 2004: Development of quantitative vitellogenin-ELISAs for fish test species used in endocrine disruptor screening. Anal Bioanal Chem 378: 621-633

NOLAN M, JOBLING S, BRIGHTY G, SUMPTER JP, TYLER CR 2001: A histological description of intersexuality in the roach. J Fish Biol 58: 160-176 
ROBERTS T 1998: Metabolic pathways of chemicals. Part 1: Herbicides and plant growth regulators. The Royal Society of Chemistry, Cambridge. 849 pp.

SAUNDERS DS, HARPER C 1994: Pesticides. In: HAYES AW (Ed.): Principles and methods of toxicology. Raven Press, New York, pp. 389-416.

SCIPPO ML, ARGIRIS C, VAN DE WEERDT C, MILLER M, WILLEMSEN P, MARTIAL J, MAGHUINROGISTER G 2004: Recombinant human estrogen, androgen and progesterone receptors for detection of potential endocrine disruptors. Anal Bioanal Chem 378: 664-669

SHIODA T, WAKABAYASHI M 2000: Effect of certain chemicals on the reproduction of medaka (Oryzias latipes). Chemosphere 40: 239-243

SUMPTER JP, JOBLING S 1995: Vitellogenesis as a biomarker for estrogenic contamination of the aquatic environment. Environ Health Perspect 103: 173-178 